\title{
ATYPICAL PRESENTATION OF NEURILEMMOMA OF BASE OF TONGUE - A CASE REPORT
}

\author{
Jagdish Prasad Purohit ${ }^{1}$, Siva Selvaraj², Kartikeya Purohit ${ }^{3}$, Vineet Kumar 4 , Sylveena Moshahary5 \\ 1 Professor and HOD, Department of ENT and Head \& Neck Surgery MLB Medical College, Jhansi, Uttar Pradesh. \\ 2Junior Resident, Department of ENT and Head \& Neck Surgery, MLB Medical College, Jhansi, Uttar Pradesh. \\ ${ }^{3}$ Senior Resident, Department of ENT and Head \& Neck Surgery, MLB Medical College, Jhansi, Uttar Pradesh. \\ 4Junior Resident, Department of ENT and Head \& Neck Surgery, MLB Medical College, Jhansi, Uttar Pradesh. \\ 5Junior Resident, Department of ENT and Head \& Neck Surgery, MLB Medical College, Jhansi, Uttar Pradesh.
}

\section{ABSTRACT}

\section{BACKGROUND}

Neurilemmoma of base of tongue is a rare disease to encounter in day-to-day practice and hence it poses a diagnostic as well as surgical challenge. We recently came across an elderly male patient who presented with a painless slow growing swelling in the left side of base of tongue. Punch biopsy of the swelling turned out to be a neurilemmoma. Here, we are discussing the various presentations of the tumour, its diagnosis and the line of management for the patient and also reviewing the literature.

\section{KEYWORDS}

Schwann Cells, Neurilemmoma, Base of Tongue, Verocay Bodies.

HOW TO CITE THIS ARTICLE: Purohit JP, Selvaraj S, Purohit K, et al. Atypical presentation of neurilemmoma of base of tongue - A case report. J. Evolution Med. Dent. Sci. 2017;6(3):255-257, DOI: 10.14260/Jemds/2017/58

\section{BACKGROUND}

The term neurilemmoma was first coined in 1935 by Stout. It also goes by the name "conventional schwannoma" or perineural fibroblastoma.[1] It is a benign, well-encapsulated and slow growing tumour arising from nerve sheath cells.[2] Whenever the tumour is arising from a small nerve, the association of tumour to its sheath is difficult to demonstrate and when it is arising from a large nerve, the nerve fibres are usually seen splayed along the surface of the tumour.[3] Usually there will be no paralysis of the nerve involved as the tumour is well encapsulated and benign.

$25-40 \%$ of neurilemmomas occur in head and neck region. ${ }^{[4]}$ Out of this, lingual neurilemmomas are rare and constitute to less than $1 \%$ of cases. Very limited literature is available on the base of tongue neurilemmoma. When the base of tongue tumour is small in size it goes unnoticed and asymptomatic. When it is larger, it might present with foreign body sensation in throat, difficulty in swallowing, voice change, etc.[5]

We are presenting one such case of base of tongue neurilemmoma, how it presented to us and its management.

\section{Case Report}

A 62-year-old male patient came to our OPD with complaints of left ear pain for 2 years. He also gave a history of mild discomfort on swallowing solid foods for 3 years. On examination, he had normal ear findings but there was a solitary swelling in the left side of base of tongue which was approximately $3 \mathrm{~cm} \times 3 \mathrm{~cm}$ in size with smooth surface covered by normal looking tongue mucosa (Figure 1). The swelling was not extending beyond the tongue. On palpation,

Financial or Other, Competing Interest: None.

Submission 05-12-2016, Peer Review 30-12-2016,

Acceptance 04-01-2017, Published 09-01-2017.

Corresponding Author:

Dr. Siva Selvaraj,

Junior Resident,

Department of ENT and Head \& Neck Surgery,

M.L.B. Medical College, Jhansi,

Uttar Pradesh, India.

E-mail: selvarajk.siva@gmail.com

DOI: $10.14260 /$ jemds $/ 2017 / 58$ it was firm, nontender and not indurated. There was no tongue deviation, no difficulty in protrusion of tongue and no dysarthria. Gustatory functions were normal. There was no associated cervical lymphadenopathy. With all the clinical findings, differential diagnosis of lingual tonsillar hypertrophy, lingual thyroid, lipoma, rhabdomyoma, neurofibroma, dermoid, schwannoma and atypical presentation of base of tongue squamous cell carcinoma were considered.

A contrast enhanced CT (Image shown in Figure 4) showed a well-defined encapsulated swelling in the left side of base of the tongue, not penetrating the lingual musculature. Punch biopsy of the tumour was done under local anaesthesia and on histopathological examination, the tumour turned out to be a neurilemmoma.

The patient was prepared for the surgery with all routine investigations. The patient was positioned supine under general anaesthesia with nasotracheal intubation. Throat packing was done to avoid aspiration of blood. Boyle Davis mouth gag was placed to expose the oropharynx and the tumour was visualised. It was held by a tonsil holding forceps and extracapsular dissection from the base was started from the anterior margin of the tumour and continued posteriorly till the tumour is removed in total.

The excised tumour is shown in figure 2. Intactness of the capsule was checked to confirm that the tumour is removed completely. The bed of the tumour was sutured with Silk to maintain haemostasis. The collected blood was cleared from throat by suctioning and throat pack was removed. Patient was reverted from anaesthesia. His post-operative stay in the ward was uneventful and he was discharged on post-operative day 5. The surgical specimen (Shown in Figure 2) was sent for histopathological examination. The HPE showed classical Antoni A and Antoni B cells which were diagnostic of Schwannoma. 


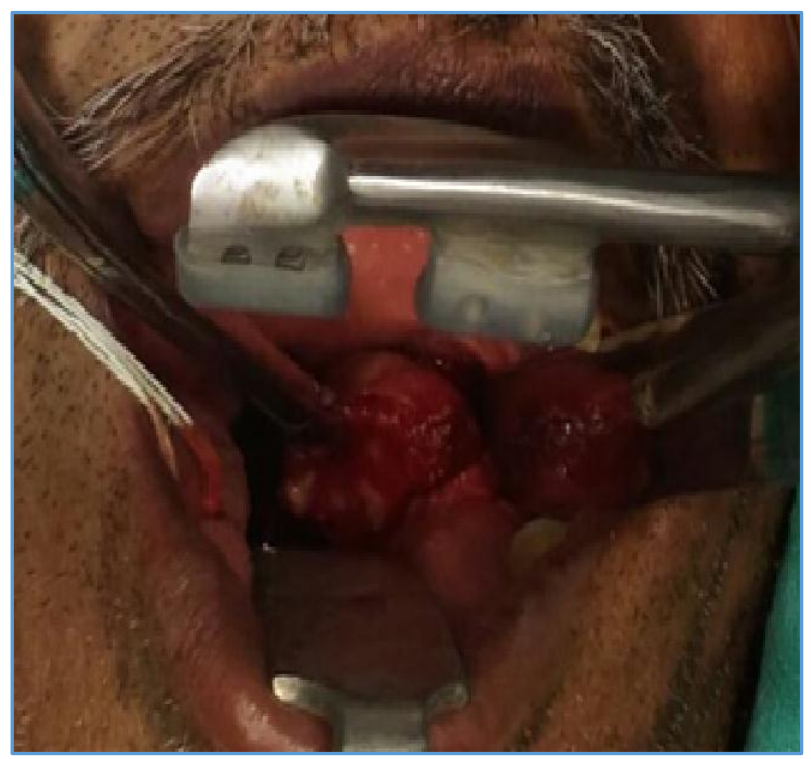

Figure 1. Showing well encapsulated Tumor in left of base of Tongue intraoperatively

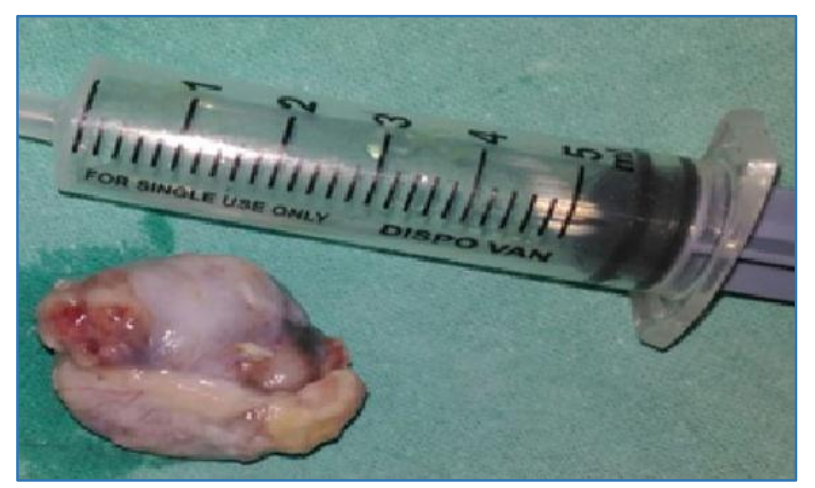

Figure 2. Showing the excised tumor $(3 \mathrm{~cm} \times 3 \mathrm{~cm})$

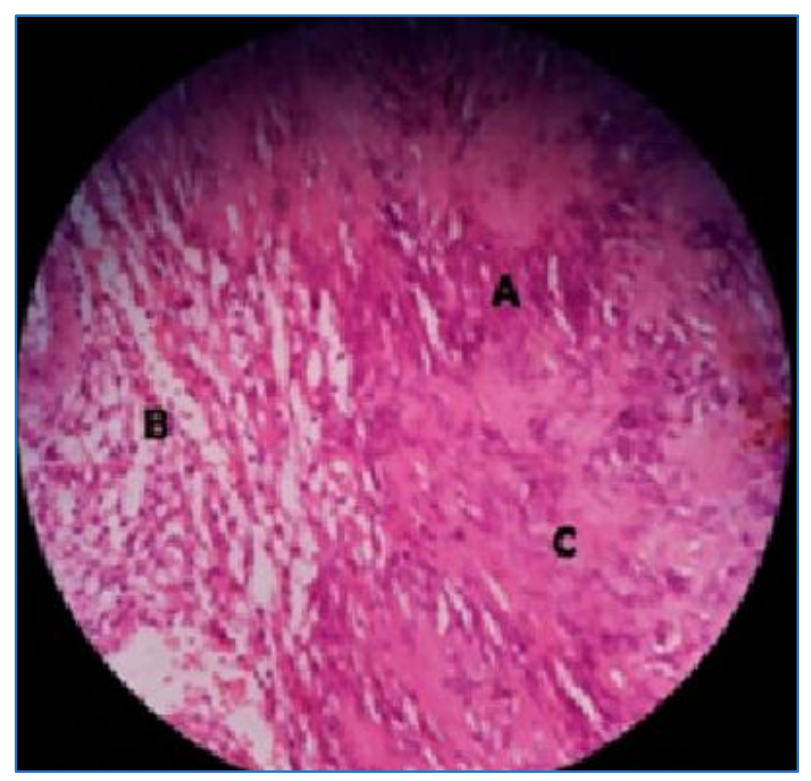

Figure 3. HPE of the excised tumor A-region, $B$-Antoni B region, $C$-Verocay Bodies

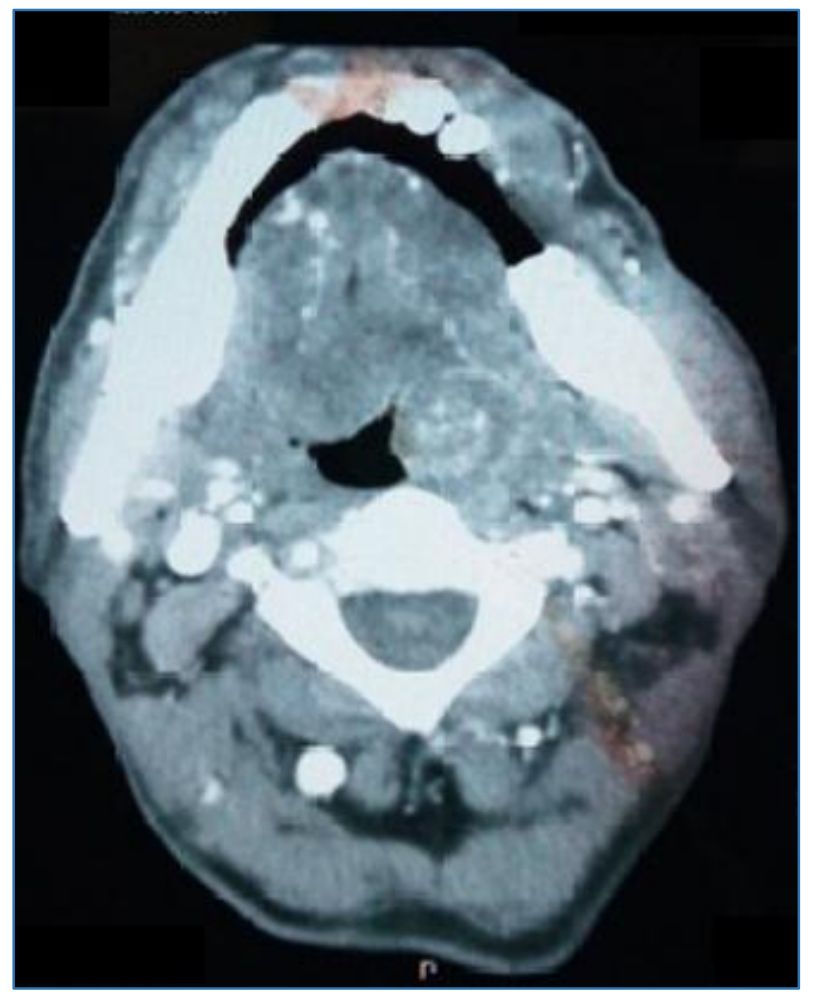

Figure 4. CECT in axial view showing the well circumscribed tumor in base of tongue

\section{DISCUSSION}

Neurilemmoma is a slow growing benign tumour arising from the Schwann cells of the nerve sheath. It is also called as a "Conventional Schwannoma".[1] 25-40\% of the cases of neurilemmomas are reported to arise from the head and neck region. Even though it is more common in the head and neck, the incidence of lingual neurilemmomas are rare and accounts only to $1 \%$ of the cases reported till date. ${ }^{[4]}$ The commonest location in head and neck is parapharyngeal space. ${ }^{[6]}$ Anterior $2 / 3^{\text {rd }}$ of tongue presentation is more common than the posterior $1 / 3^{\text {rd }}$ or base of tongue. [7]

In our case, the patient was an elderly male with tumour in the left of base of tongue. According to the literature, base of tongue neurilemmomas present usually at the age ranging between 20 to 40 years, with no sex predilection. But in our case, the patient was a 62-year-old male. This can be because of the delayed presentation of the neurilemmoma with less severe symptoms due to its benign and slow growing nature. Malignant change in a neurilemmoma is a very rare entity. ${ }^{[8]}$ Our patient presented with left ear pain and discomfort on swallowing for almost 3 years. Other symptoms can be slow growing swelling, difficulty in swallowing, deviation of tongue, difficulty in tongue protrusion, snoring, slurred speech, globus, etc.

Neurilemmomas usually arise from the nerve sheath of sensory component of any of the cranial nerves or their branches except optic and olfactory nerves ${ }^{[9]}$ as they are direct extensions of brain matter. Vestibulocochlear nerve is the commonest of the cranial nerves to get involved. Following this trigeminal, glossopharyngeal and vagus nerves come in decreasing order of frequency of involvement. Hypoglossal nerve has the least chances to get involved in a schwannoma.[10] As our patient was having referred pain in his left ear, there is a high chance of the tumour arising from the 
left glossopharyngeal nerve. Nerve of origin of the neurilemmoma can be found only in half of the cases.[11]

Radiological investigation advocated in a benign base of tongue swelling is magnetic resonance imaging and contrast enhanced CT. Out of these two modalities, MRI is the investigation of choice for neurilemmoma.[12,13] In MRI neurilemmoma will appear to be hypointense to tongue musculature in T1 images and in T2 images it will appear as a homogenous swelling with degenerative changes within. In our case, we did a CECT for the patient and the swelling was a well-encapsulated swelling not infiltrating the musculature underneath it.

The histopathological examination of the swelling showed features diagnostic of conventional schwannoma. The features in HPE in a schwannoma are arrangement of Schwann cells in two cellular patterns viz- Antoni A and Antoni B pattern. Antoni A pattern is highly cellular with elongated Schwann cells with nuclei arranged in palisading pattern. Antoni B pattern is less dense and irregularly arranged Schwann cells. Verocay bodies are the zones between Antoni A and Antoni B which are devoid of any nuclei.[14] As the origin of the tumour is from the nerve sheath cells, the tumour will show S-100 staining positivity. But even tumours like neurofibroma will show S-100 in their cells.[15]

The treatment of choice for neurilemmoma of tongue base is surgical excision.[16] The approach to the base of tongue can be done through intraoral route itself in cases where the tumour size is small as in our case. In cases where the tumour size is large and removal through intraoral route is not possible, then in such cases approaches like median labiomandibular osteotomy, lateral pharyngotomy, submandibular, transhyoid and suprahyoid pharyngotomy[15,17,18] are considered.

\section{REFERENCES}

[1] Kurtkaya-Yapicier 0, Scheithauer B, Woodruff JM, et al. The pathologic spectrum of schwannomas. Histol Histopathol 2003;18(3):925-34.

[2] Conley JJ. Neurogenous tumors in the neck. AMA Arch Otolaryngol 1955;61(2):167-80.

[3] Kragh LV, Soule EH, Masson JK. Benign and malignant neurilemmomas of the head and neck. Surg Gynecol Obstet 1960;111:211-8.

[4] Saydam L, Kizilay A, Kalcioglu T, et al. Ancient cervical vagal neurilemmoma: a case report. Am J Otolaryngol 2000;21(1):61-4.
[5] Van der waal I, Snow GB. Benign tumors and tumor-like lesions. In: Cummings CW, Fredrickson JM, Harker LA, et al, (eds). Head and neck surgery. St: Louise, Mosby 1998:1407-17.

[6] Franzen A, Koegel K. Neurinoma of the neck area. Laryngorhinootologie 1996;75(4):250-3.

[7] Wright BA, Jackson D. Neural tumors of the oral cavity. A review of the spectrum of benign and malignant oral tumors of the oral cavity and jaws. Oral surg oral med oral pathol 1980;49(6):509-22.

[8] Abell MR, Hart WR, Olson JR. Tumor of the peripheral nervous system. Hum Pathol 1970;1(4):503-51.

[9] Sawhney R, Carron MA, Mathog RH. Tongue base schwannoma: report, review, and unique surgical approach. Am J Otolaryngol 2008;29(2):119-22.

[10] Beldarrain GM, Canton FG, Garcia-Monco JC. Hypoglossal schwannoma: an uncommon cause of twelfth-nerve palsy. Neurologia 2000;15(4):182-3.

[11] Mehrzad H, Persaud R, Papadimitriou N, et al. Schwannoma of tongue base treated with transoral carbon dioxide laser. See comment in PubMed Commons below Lasers Med Sci 2006;21:235-7.

[12] Spandow O, Fagerlund M, Bergmark L, et al. Clinical and histopathological features of a large parapharyngeal neurilemmoma located at the base of tongue. ORL 1999;61(1):25-30.

[13] Jager R, Rich P. Extra-axial tumors: Grainger and Allison's diagnostic radiology: a text book of medical imaging. $4^{\text {th }}$ edn. Orlando FL: Churchill Livingstone, Inc 2001:p 2339.

[14] Sawhney R, Carron MA, Mathog RH. Tongue base schwannoma: report, review and unique surgical approach. American Journal of Otolaryngology-Head and neck Medicine and Surgery 2008;29(2):119-22.

[15] Hsu YC, Hwang CF, Hsu RF, et al. Schwannoma (neurilemmoma) of the tongue. Acta Otolaryngol 2006;126(8):861-5.

[16] Chandra M, Singh P, Venkatchalam VP, et al. Tongue schwannoma: a case report with review of literature. JK Practitioner 2013;18(1-2):28-34.

[17] de Bree R, Westerveld GJ, Smeele LE. Submandibular approach foe excision of a large schwannoma in the base of tongue. Eur Arch Otorhinolaryngol 2000;257(5):2836.

[18] Ying YL, Zimmer LA, Myers EN. Base of tongue schwannoma: a case report. Laryngoscope 2006;116(7): 1284-7. 